\title{
DIGITALIZATION OF FINANCIAL REPORTING IN LOCAL GOVERNMENTS OF THREE MONTENEGRIN REGIONS - CURRENT SITUATION AND PERSPECTIVES
}

\author{
Ana Lalević Filipović \\ Vladan Martić \\ Selma Demirović
}

Received: 14. 6. 2016

Original scientific paper

Accepted: 21. 5. 2018

UDC 657.31:004>352(497.16)

DOI https://doi.org/10.30924/mjcmi/2018.23.1.59

\begin{abstract}
The aim of this paper is to analyse the level of digitalized financial reporting process in local governments of three different Montenegrin geographic regions and to estimate the level of harmonization with the modern achievements in the domain of computerization of accounting systems. For that purpose, two research approaches (direct insight and survey) are used to examine the general hypothesis. This hypothesis states that the digitalization of financial reporting in different regions in Montenegro
\end{abstract}

\section{INTRODUCTION}

At the end of the last century and at the beginning of the new millennium, turbulent developments in the socio-economic and political environment left a trail in Montenegro and contributed to unequal regional development in this country. At the same time, at the beginning of the $21^{\text {st }}$ century, dynamic developments were taking place in the field of statutory accounting regulation (2002, 2005, 2008, 2011, 2015, 2016 and 2017), depends on the level of the accounting culture of companies, but also on their size, activities and normative acts. The fact that similar research has not been previously conducted in Montenegro, or in the neighbouring countries, which makes this study an original contribution.

Keywords: digitalization of financial statements, information technology (IT) achievements, accounting profession, local governments, EU.

which were in line with the EU Directives, as well as with World Bank recommendations. However, the general attitude of the professional and academic public was that the legislative solutions are good, but that there are problems regarding their implementation. Therefore, the authors of this paper wanted to analyse the developments in accounting standards of legal entities in light of the regional development of local governments in Montenegro, circumstances on the global stage, and taking into consideration

\footnotetext{
* Ana Lalević Filipović, PhD, associate professorUniversity of Montenegro, Faculty of Economics, Jovana Tomaševića 37, 81000 Podgorica, Montenegro, e-mail: analf@ac.me

${ }^{* * *}$ Vladan Martić, PhD, assistant, University Mediterranean, Podgorica, Montenegro, e-mail: vladan.martic@unimediteran.net

${ }^{* * *}$ Selma Demirović, PhD candidate, University of Montenegro, Faculty of Economics, Podgorica, Montenegro, e-mail: selma987@t-com.me
} 
Montenegro's intention to be part of the European Community. Additionally, authors wanted to identify factors that have impact on accounting and information development of the above-mentioned local governments.

Relying on the existing literature on this topic, the paper intends to prove the following hypothesis:

$\mathrm{H}_{0}$ : The level of regional development, the size and the activity of the company, as well as the accounting legislative norm are connected with the level of accounting culture in the domain of IT in particular regions of Montenegro.

Macroeconomic environment of Montenegrin regions was analyzed with the direct insight into the municipalities' web pages in order to collect information about the level of development of different regions, as well as to acquire knowledge about the level of IT literacy of local government units with the focus on Accounting Information System of supporting institutions. These issues are very important because IT plays a key role in modern business as it enables companies to digitalise manual operations and process information much faster. At the same time, the Internet has enabled new forms of communication and new methods of processing financial information.

The analysis of the influence of certain factors that determine the degree of digitalisation in financial reporting, as well as correlation between those factors, has been carried out by applying two research approaches. The first approach included all companies listed on the stock exchange in Montenegro, which in previous period showed discipline in financial reporting. The second research approach was conducted by means of the survey which included a complete accounting community in Montenegro. The main goal of this research was to draw conclusions about accounting and information literacy of the members of the accounting profession in certain regions.

The paper is divided in four parts. Introduction is followed by a review of literature, and by analysis of the macroeconomic environment of local government units in Montenegro, with a special emphasis on the IT support of the municipal websites. The third part focuses on the research methodology and the description of data used for empirical analysis. The last part of the paper, before conclusion and discussion, offers empirical results of the research.

The fact that the same or similar research was not done in Montenegro, nor in the neighbouring countries, adds to the originality of the research, representing a pioneering step in this research area.

In that sense, authors believe that the research can be useful for: (1) the accounting profession; (2) members of the accounting community of local governments of Montenegro, (3) for identifying the deficiencies of the existing IT accounting information support, and (4) for the realization of the benefits provided by the digitalized financial statements, which should lead to its integration into AIS (Accounting Information System).

\section{LITERATURE REVIEW}

In recent years, several papers have pointed out the benefits of presenting financial information over the Internet in comparison with traditional printed reports. (Lymer et al., 1997, Ashbaugh et al., 1999, Oyelere et al., Smith, 2003; Fisher et al., 2004; Hodge et al., 2006; Wagenhofer, 2003). Emphasizing benefits for stakeholders, the authors put special emphasis on cost reduction and cost-effectiveness of data 
acquisition, greater dynamics and flexibility of reports in the desired format, making them available to all users, both nationally and internationally (Ashbaugh et al., 1999; Allam et al., 2003; Lymer, 1999;). Some authors (Hoffman, et al., 2012) wanted to emphasize that digitalized financial statements are not necessary, but they are inevitable.

Our research revealed that there are studies not focused only on dealing with digitalization of financial reporting in different countries (US (Petravick et al., 1996; Ashbaugh et al., 1999;), UK (Lymer, 1997; Marston et al., 1998; Craven et al., 1999), Japan (Marston, 2003), New Zealand (Oyelere et al., 2003) and Ireland (Abdelsalam et al., 2007), but rather on the correlation between specific characteristics of the company and the digitalization of financial reporting (Ashbaugh et al., 1999; Craven et al., 1999; Ettredge et al., 2001; Pirchegger et al., 1999; Brennan et.al, 1999; Bonson et.al, 2006 , Allam et al., 2003; Oyelere et al., 2003; Marston et al., 2004; Barako et al., 2008; Ezat et al., 2008;). In that context, authors note that literature available in the field of IT financial report-ing can be divided into three segments, ac-cording to the research methods used and the results that they provided: Descriptive; Comparative and Explanatory (Zaimovic, et al., 2015; Marston et al., 2004).

Regarding the countries in the region, there are surveys that advocate the use of information technologies in accounting at the country level, but not at the level of the regions. Cvijetić, M. (2014) compared Serbia and the EU countries and concluded that in Serbia only $26 \%$ of the surveyed companies have a website, while a research on the site is possible in $15 \%$ of the cases. When it comes to financial reports, they are available either in HTML format (29\%) or PDF (47\%), while none of the reports were available in XBRL format. Unlike Serbia, the survey shows that EU countries are strongly ahead in this area with $46 \%$ of surveyed companies having a map of the web site, $44 \%$ enabling successful website research. Financial reports in HTML format represented $62 \%$ of the total number of reports researched, PDFs $78 \%$, while XBRL format was found in $6 \%$ of sampled companies. When it comes to the use of accounting information published on the website, an interagency survey was conducted in Slovenia, where it is stated that $52.6 \%$ of companies publish their accounting information on their web pages and that on average $40.2 \%$ of users actually use this information (Dolinšek, 2014). Also, the research by Pervan (2005) compared the company's shares in the financial markets of Croatia and Slovenia. The results of a comparative analysis involving Slovenia (30 companies included) and Croatia (55 companies missing) and where the Internet Financial Reporting (IFR) used as a measurement instrument indicates that Slovenia is much more advanced than Croatia. Namely, the results show that the average IFR score for the companies included in the research in Croatia was 6.85, which is significantly lower than the Slovenian company, the glanded indicator is 17. Another research (Pervan et al., 2017) used panel analysis in order to analyse the level of transparency in digital financial reporting of Croatian banks. Research was conducted for the period 2010 - 2014.

Ashbaugh (1999) analyzed a sample of 290 companies and found that there was a positive correlation between the size of the company and the publication of information on the website. Similarly, the author Ettredge et al. (2001) examined whether there is a relationship between the volume of published reports on the website and the company's characteristics. They concluded that the level of publication on the website is positively correlated with the size of the 
company. Furthermore, researchers (Craven et al., 1999) examined 206 major UK companies in order to determine, inter alia, whether the size of the company and the nature of the activity had an impact on publishing information on the website. The analysis found that only the size of the company is a statistically significant variable. Pirchegger (Pirchegger et al., 1999) analyzed German and Austrian listed companies (in two periods) and confirmed the above-mentioned hypothesis among sampled companies in Austria, but not in Germany. At the same time, another research (Brennan et al., 2000) conducted an analysis with Irish companies and concluded, among other things, that large companies have a stronger culture in terms of publishing financial information, and that this culture is dominated by financial sector companies, as well as companies from the services sector. Analyzing the practice of publishing financial reports on a sample of 300 EU companies, Bonson comes to the conclusion (Bonson et al., 2009) that there is a greater discipline of financial reporting with companies in Northern and Central Europe than companies from Southern Europe. The analysis has shown that there is a correlation between the industry sector and the size of the company with a transparency index. Marston (Marston et al., 2004) was using the multivariate analysis and confirmed that among the five factors (size, profitability, trading in shares, risk and international trade), only the size of the company (measured by market capitalization) had a significant impact on the digitization of financial reporting.

From the point of view of the local authorities, several studies dealing with IT issues in the field of financial reporting were observed. Said et al., 2001 examined the number of local authorities that practice digital reporting. They found that only a small percentage of local authorities practice digital reporting. The results of their study are mainly descriptive and are describing the number of government bodies practicing digital reporting. Another study (Ryan et al., 2002), dealing with financial reporting of local governments, reviewed the annual reports of 36 Australian Local Councils (20072009) and concluded that the size of local government is positively correlated with the quality of financial reporting.

Furthermore, Bolivar (Bolivar et al., 2007) did not find any visible link between demographic or socioeconomic characteristics and better practice of publishing financial information over the Internet in the context of regional governments in Spain. A study by Bolivar et al. (2006) concluded that administrative culture is an important factor in determining the way a country uses the Internet in terms of transparency in financial reporting. In this domain, an interactive research in New Zealand (Laswad et al., 2005) with logit analysis indicated that local governments are using the Internet financial reporting on different levels, depending on their financial leverage, municipal wealth, press visibility and council type.

\section{MACROECONOMIC ENVIRONMENT OF LOCAL GOVERNMENT UNITS IN MONTENEGRO}

The system of local governments in Montenegro is one-sided with monotype model of organization with the municipality as the basic territorial unit. Geographically, Montenegro is divided into 23 municipalities with 1256 settlements, 40 of which are urban-type. The majority of the population is concentrated in urban areas where $64 \%$ of the population lives. 23 municipalities are classified in three regions: Central (central), which belongs to four municipalities (Podgorica, 
Table 1: Indiciators of regional development in Montenegro (2013-2015)

\begin{tabular}{|cc|r|r|r|r|}
\cline { 3 - 6 } \multicolumn{1}{c|}{} & \multicolumn{2}{c|}{$\begin{array}{c}\text { UNEMPLOYMENT } \\
\text { (in \%) }\end{array}$} & $\begin{array}{c}\text { PRETAX } \\
\text { INCOME JLS } \\
\text { (in } € \text { ) }\end{array}$ & $\begin{array}{c}\text { PER } \\
\text { CAPITA } \\
\text { (in } € \text { ) }\end{array}$ & \multicolumn{1}{c|}{ SMEs } \\
\hline \multirow{2}{*}{$\begin{array}{c}\text { CENTRAL } \\
\text { REGION }\end{array}$} & 2013 & $13,04 \%$ & 786.172 .893 & $2.678,53$ & 9.608 \\
\hline & 2014 & $12,77 \%$ & 766.987 .824 & $2.613,17$ & 10.245 \\
\hline \multirow{2}{*}{$\begin{array}{c}\text { SOUTHERN } \\
\text { REGION }\end{array}$} & 2015 & $14,55 \%$ & 764.674 .952 & $2.605,29$ & 10.833 \\
\hline \multirow{2}{*}{$\begin{array}{c}2013 \\
\text { NORTHERN } \\
\text { REGION }\end{array}$} & 2015 & $11,47 \%$ & 407.137 .670 & $2.738,30$ & 8.833 \\
\cline { 2 - 7 } & 2014 & $11,98 \%$ & 402.920 .671 & $2.709,94$ & 9.699 \\
\hline
\end{tabular}

Source: Adopted by Report of realization of Action Plan of Regional Development Strategy of Montenegro 2014-20204

Danilovgrad, Nikšić and Cetinje), Southern (coastal) which includes six municipalities (Bar, Budva, Herceg Novi, Tivat, Kotor, Ulcinj) and Northern region, in which 13 municipalities are located (Kolašin, Bijelo Polje, Plužine, Šavnik, Andrijevica, Gusinje, Plav, Berane, Mojkovac, Žabljak, Pljevlja, Petnjica, Rožaje). These regions are characterized by unequal development, and this is often a factor that places Montenegro among less developed countries compared to the EU member states. The Northern region is formed by the largest number of local government units, which geographically occupies more than $52 \%$ of the Montenegrin area and has the largest natural wealth of Montenegro, but is also the least developed region. The reasons for this situation are dating back to the ' $90 \mathrm{~s}$, in which hyperinflation, as well as the collapse of large industrial giants located precisely in this area, led to significant socio-economic disparities. Taking into account the global crisis in the first decade of the new millennium, it is quite understandable why Ministry of Economy (2012 -2014) concluded that according to the development index, the Northern region is the least developed. The most developed units of local government are coming from the coastal region (Budva is in the first place), while the capital city of Montenegro - Podgorica is the most developed unit from the central region of Montenegro.

The reason for the significantly unequal regional development in Montenegro is found in the outflow of the population, high unemployment, and thus the small supply of new jobs as well as the low budget revenues of the local government units of the Northern region compared to other regions in Montenegro. In general, according to all observed indicators, the Northern region is in the worst position, as evidenced by the data given in the table (Table 1):

Realizing that uneven regional development in Montenegro is becoming more apparent, the Government of Montenegro adopted the Regional Development Strategy (2014-2020) in which the achievement of a more balanced socio-economic development of all local government units and regions

\footnotetext{
1 http://www.mek.gov.me/ResourceManager/FileDownload.aspx?rid=173411\&rType=2, accessed on: 19.05.2017
} 
based on competitiveness, innovation and employment is required. Since the adoption of the Strategy, positive real economic growth was recorded: $1.8 \%$ in 2014 and $3.2 \%$ in $2015^{2}$ which is considered a significant progress, but not sufficient enough to achieve a balanced regional development of Montenegro.

\subsection{Digitalization of financial reporting in the context of the institutions of local government units}

The application of modern information and communication technologies has three key priorities in terms of achieving balanced regional development: (1) smart growth, (2) sustainable development and (3) inclusive growth. It is pointed out that better macroeconomic environment as well as a more balanced regional development of Montenegro can be achieved, among other things through "accelerating the development of information and communication technologies and digitalization, electronic business and networking ${ }^{3 "}$. However, according to the available data (observing the period 2012-2015), Montenegro records a downward trend or, at best, a stagnation phase in the area of digital financial reporting. The cause fo this is found in the lack of projects in the IT area ${ }^{4}$, as Montenegrin business environment does not show significant demand for the use of IT (except banks and providers of telecommunication services).

The Law on Accounting is no longer applicable to local government regulations in the aspect of financial reporting (Official Gazette of Montenegro, No. 052/16 of 09.08.2016, Article 1). Article 6 of the Rulebook (Official Gazette of Montenegro, No. 32/10 of 07.06.2010, 14/11 from 11.03.2011) states that "Municipalities submit quarterly / annual financial reports to the Ministry...". At the same time, the aforementioned Rulebook does not emphasize the form of financial statements that municipalities should submit, nor the obligations of municipalities regarding their public disclosure.

Authors of this paper have tried to establish the level of IT literacy of financial reporting in the units of local self-government in Montenegro. At the top of the survey were companies of different activities originating from the three regions of Montenegro. Also, during the research, particular emphasis was placed on the existence of websites and information that are present on the published and available financial reports (report on the budget or cash flows), as well as on certain acts that are in the domain of transparency of municipal operations. The authors are convinced that such a conception and scope of research will be in the fusion of relevant testing of hypotheses.

By analyzing the website content, it is evident that the websites of municipalities are focused on the provision of general information and tourist services (especially the coastal region). On the other hand, the publication of financial reports on the website is not legally regulated. Because of this, and due to the circumstances unaffected by the importance of qualitative determinants of financial statements, local governments also have a low level of transparency in financial reporting. Likewise, authors noticed that information on the website is updated

\footnotetext{
2 www.gov.me/ResourceManager/FileDownload.aspx?rId=243695\&rType=2, available at: 19.06.2017.

3 http://www.privrednakomora.me/poslovni-ambijent-javne-rasprave-projekti-aktuelnosti/informacionetehnologije-stanje-i-perspektive, available at: 19.06.2017.

4 http://www.privrednakomora.me/poslovni-ambijent-javne-rasprave-projekti-aktuelnosti/informacionetehnologije-stanje-i-perspektive, available at: 19.06.2017.
} 
only when a need arises, and none of the municipalities allow the visitors to subscribe to the RSS feed. Additionally, not even one analyzed website is optimized and adapted for small screens such as tablets and smartphones (RWD - Responsive Web Design). This fact is particularly important if we take into account that the percentage of percentage of website access from mobile devices is close to $50 \%$ and Google also rarely lists websites without RWD in search results.

\section{INTRODUCTORY CONSIDERATIONS AND RESEARCH METHODOLOGY}

Authors of this paper tried to determine whether there is any correlation between variables (size of the enterprise, activity, national accounting framework) and perceptions of the companies in the region regarding the digitalization of financial reporting. The first step was related to the analysis of the website content of the companies listed on the Montenegro Stock Exchange. The procedure was conducted through direct access to the websites of companies belonging to certain municipalities in Montenegro in the period from 15 June to 5 July 2017. The intention was to look whether companies that have an obligation to submit financial statements to the competent authority in accordance with the national accounting legislation (Article 17, Accounting Law) comply with the regulations and publish the information regularly on their webistes. Regarding the public disclosure of financial statements, the second intention was to discover whether the government has a uniform accounting standard with all quoted companies, no matter which municipality they come from, which activities they perform and what size they are.

Data collection was carried out through a structured web survey - which was distributed to 904 electronic addresses in the accounting community. The reasons for making such a sample are multiple, but the key one is that the accounting community is ultimately responsible for shaping business environment of national economies through information that it provides to interested stakeholders ${ }^{5}$.

Furthermore, as the survey was carried out in the period of very dynamic events in the accounting profession, accountants and auditors were able to experience the advantages and disadvantages of the existing accounting IT solutions, as well as the entire AIS. In accordance with the above-mentioned, authors considered that members of the accounting community, in this context, fulfill all the characteristics of a representative sample. A total of 303 respondents answered the questionnaire, which makes a total response rate of $33 \%$. The size of the sample was considered sufficient for carrying out the research (Bonson et al., 2009; Gray et al, 2009; Felden, 2011; Steenkamp et al, 2012). Data entry was done automatically via Google Forms, while the processing of data was done in IBM SPSS Software.

Analysis of empirical research results required the use of statistical techniques that would be in line with the nature of the data collected, the method of measurement, the nature of the set objectives and the research hypothesis. In this respect, the methodological procedure required that at the beginning, for each variable the percentage of the missing data was determined. Afterwards, crosstabulation (Crosstabs) was done, while the

\footnotetext{
5 During the research on this topic, we used the results of the conducted survey (implemented in the period from 1st to 31st March of 2016), PhD Vladan Martić, "Application of XBRL in the Function of Improving the Quality of Financial Reporting in Montenegro”, University of Mediterranean, Montenegro Business school, 2017.
} 
rating of statistical significance, as well as the correlation was determined by the Hi-square independence test, as Kramer's V (Cramer's $V)$. Authors believe that this approach is relevant for drawing conclusions and for examining the credibility of the hypothesis.

In the end, authors consider that the survey period, 2016 (the survey) and 2017 (direct insight) is relevant from the chronological aspect.

\section{RESULTS}

\subsection{Perception of the issuer on the Montenegrin Stock Exchange in terms of digitalization of financial reporting}

Transparency and public disclosure of financial statements are fundamental for improving the quality of financial reporting. They also show the most effective way to enable shareholders easy access to financial operations of the company. Therefore, in the first part of the research, the authors relied looked at the companies whose securities are traded on Montenegro stock exchange and which publish financial statements on that website in particular format. For reviewing the website of the Montenegro Stock Exchange (MSE) (the part where financial statements are uploaded), only issuers (independently of lists they belong to) which in any format submitted financial statements $\left(Q_{1}\right.$ of 2017 and financial/audit report for 2016) were included. The aim of this approach is not to favour any company according to the list it belongs to (A and / or B list, or free market), but to analyze the level of accounting and IT literacy among companies that delivered financial statements. When it comes to the sample, this study relies on the method of selecting samples outlined in earlier research (Khalay, 2013; Azleen et al, 2015), which put the focus of companies on the stock market. Bearing in mind that these are the companies that have to meet the highest reporting standards for admission of their securities to the stock exchange, the sample of companies is considered representative.

Authors tried to find out to what extent the listed companies understand the importance of disclosure of accounting information, by analyzing the content of the companies' websites. As can be observed (Table 2 and Figure 1), the largest number of financial reports published on the stock market website are issued by companies located in the central region of Montenegro, with the dominance of companies from the municipality of Podgorica (44\%). Regarding the posession of a website, the situation is not far off $(55 \%)$, as well as regarding the publication of financial statements on their own website $(82.3 \%)$, indicating that the companies located in the capital of Montenegro understood the importance and the purpose of financial reporting (Brennan et al., 2000). This situation is a consequence of the fact that the largest companies in Montenegro are located in Podgorica and that in most of these companies influence of foreign capital is presented (especially in banking institutions). At the same time, the banking sector is subject to provisions of the Decision on Public Disclosure of Data ${ }^{6}$, which is reflected consequently on the quality of financial reporting. Report on compliance with standards and regulations - ROSC has also confirmed that in the banking sector the highest quality of financial reporting is obtained. In the part dealing with the progress of the banking sector in Montenegro, ROSC states:

\footnotetext{
Decision on Public Disclosure of Data (Official Gazette of Montenegro, No. 02/12 of 11.01.2012), as well as the provision of the Law on Banks ("Official Gazette of Montenegro", No. 17/08 of 11.03 .2008, 44/10 of 30.07.2010, 40/11 of 08.08 .2011 )
} 
Figure 1. Transparency of financial reporting of companies (MSE)-regions

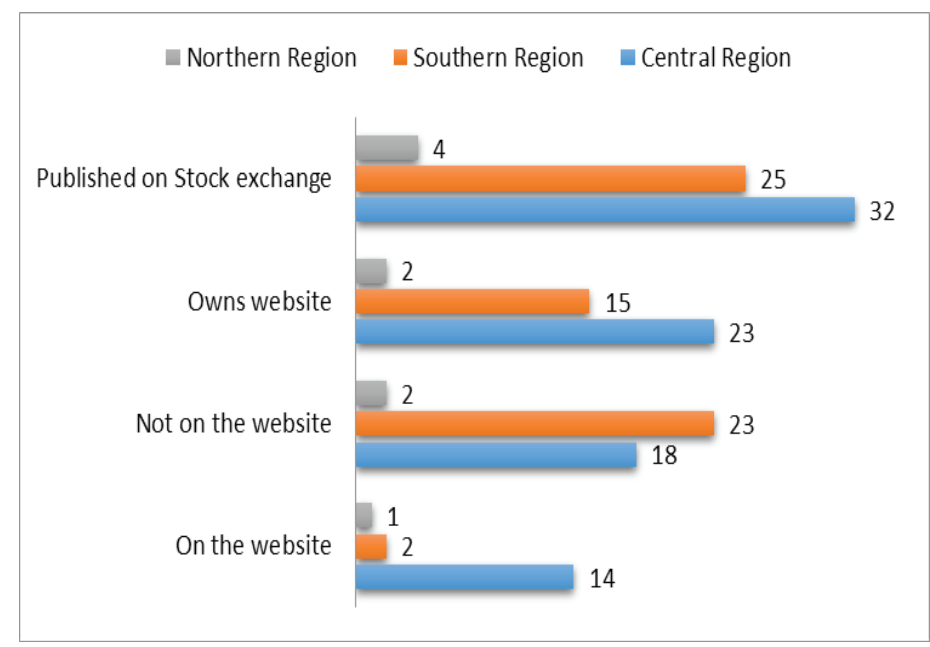

Source: Author's calculation from the database http://www.montenegroberza.com

"The quality of the financial statements of several Montenegrin banks is comparable to the financial reports of banks of equivalent size in the European Union".

Furthermore, authors noticed that the coastal region was recognized as tourist region, as the strategic document of the Government of Montenegro recognised tourism as a priority sector of development. Although tourism was highlighted as one of the instigators of a balanced regional development, it did not attach great importance to the digitalization and transparency of financial reporting. Namely, out of the 25 companies that submitted their financial statements on the stock exchange, $37 \%$ of them have a website, while more than a half $(53.4 \%)$ did not disclose financial statements on their website. Authors believe that this situation is a consequence of the fact that publication of financial reports on company's website is not legally regulated, and that small/mediumsized companies in the tourism and catering sector are dominant in the structure of the activities of the coastal region. Since they do not aim at attracting investors, their websites (if they have one) are predominantly focused on the provision of tourist services.

In the end, the Northern region is in the worst position in this segment, since only four companies submitted financial statements on the stock market website, out of which only one company disclosed financial statements on its website. The reason for such an alarming state of financial reporting jas to do with problems of the Northern region, where most companies place their priority on their on-going business.

Survey results show that many companies (especially small and medium-sized) believe that financial reporting is considered a business secret and that is mainly conducted in the domain of legal obligation (Martić, 2017). Results indicate that „Less than a third of the quoted companies (27\%) publish their financial statemetns on their website." If that fact is looked at in the context of the research, authors see a stagnation in the domain of transparency of financial reporting and the availability of reports on the company's website. This indicates insufficient level of awareness about the importance of transparent financial reporting. 
Journal of Contemporary Management Issues

Table 2. Transparency of fin. reporting of companies (MSE)-municipalities

\begin{tabular}{|c|c|c|c|c|c|}
\hline & Town & $\begin{array}{l}\text { On the } \\
\text { website }\end{array}$ & $\begin{array}{l}\text { Not on the } \\
\text { website }\end{array}$ & $\begin{array}{c}\text { Own } \\
\text { website }\end{array}$ & $\begin{array}{l}\text { Published } \\
\text { on Stock } \\
\text { exchange }\end{array}$ \\
\hline \multirow{3}{*}{$\begin{array}{l}\text { Central } \\
\text { region }\end{array}$} & Podgorica & 14 & 13 & 22 & 27 \\
\hline & Nikšić & 0 & 3 & 0 & 3 \\
\hline & Cetinje & 0 & 2 & 1 & 2 \\
\hline \multirow{5}{*}{$\begin{array}{l}\text { Southern } \\
\text { region }\end{array}$} & Budva & 0 & 5 & 3 & 5 \\
\hline & Bar & 2 & 4 & 5 & 6 \\
\hline & Kotor & 0 & 5 & 2 & 5 \\
\hline & Tivat & 0 & 3 & 3 & 3 \\
\hline & Herceg Novi & 0 & 3 & 0 & 3 \\
\hline
\end{tabular}

Furthermore, authors were interested in investigating financial reporting habits of more representative companies in Montenegro. These are companies that have to meet certain standards and are accordingly classified into two categories: List A (7 companies) on the Stock Exchange and List B (11 companies). Of all the listed companies, $77 \%$ are located in Podgorica, while 16\% are located on the coast and only $6 \%$ in the northern part of Montenegro. By inspecting the website of the Securities and Exchange Commission (SEC) concerning the listed companies, authors found that one company from the A list and one from the B list have not submitted financial statements (Balance Sheet and Income Statement), which led to the conclusion that the implementation of regulations on both lists is cleraly evident.

By reviewing the websites of those companies, authors note that more than $55 \%$ of companies make their financial statements available on their websites, with A listed companies showing more discipline (85\%) than B listed companies (36.3\%). Similar results were obtained in some earlier studies (Deller et al. (1999), Bogdan et al. (2008).
The most common formats for delivering financial statements both to SEC and Montenegro stock exchanges are statistical formats, PDF and Excel. The data is virtually "locked" within these formats, which prevents their efficient exchange and causes a number of problems that arise in the collection and processing of data and reports. The results are completely compatible with the results of the Allam and Lymer research (2003).

National legislation provides penalties (Article 38, Law on Accounting) for any legal entity that fails to submit financial reports to the competent authority. The powers of the SEC are very narrow, and the ROSC Report states that "SEC cannot impose fines or sanctions on inadequate financial reporting". In this context, the authors conclude that the obligation of transparent financial reporting exists, but that the obligation is not binding.

In general, authors consider that companies still do not see the website as a need, but as an imposed obligation and unnecessary cost. Therefore, companies do not readily 
invest in website development. Design and optimization of content for access through different clients are made through Web browsers on various platforms, RSS and other aggregators, Search Engine Optimization, content availability and others. Regarding this, it seems that one the most common problem is that companies forgot about their websites the day they were created.

In this stage of the research, authors came to the conclusion that the size of the company, its activity, as well as the existence of certain binding normative acts can also determine the level of accounting discipline.

\subsection{Analysis of the survey of local government units in Montenegro}

From the perspective of regional representation of respondents who took part in this research, authors come to the conclusion that $2 / 3$ of the respondents come from the central part of Montenegro (Figure 2), which is not matched with the regional share of the population according to the 2011 demographic statistics, where $47 \%$ of the population originated from the Central region, $27 \%$ from the North, and 23\% from the South. Authors believe that this circumstance will not significantly affect the conceptualization
Figure 2: Regional representation of respondents

Regional representation of respondents in the observed sample

- Central region - Southem region " Northem regian

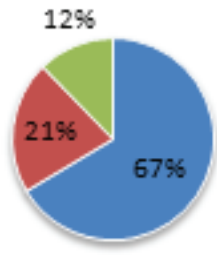

of conclusions in certain sub-segments of the research.

Small and medium-sized enterprises (SMEs) in the structure of the Montenegrin economy account for $99 \%$ of the total number of enterprises, making $60 \%$ of GDP and $67 \%$ of total employment. If the size of an enterprise is taken as a criterion (Article 5 of the Law on Accounting), authors note that the majority of sampled companies belong to SMEs, which is compatible with the currently represented structure of legal entities by size in Montenegro (Monstat, 2012). According to the data from 2015, $12.57 \%$ of total SMEs (without entrepreneurs) are located in the Northern region of Montenegro,

Figure 3: Regional share of companies by size

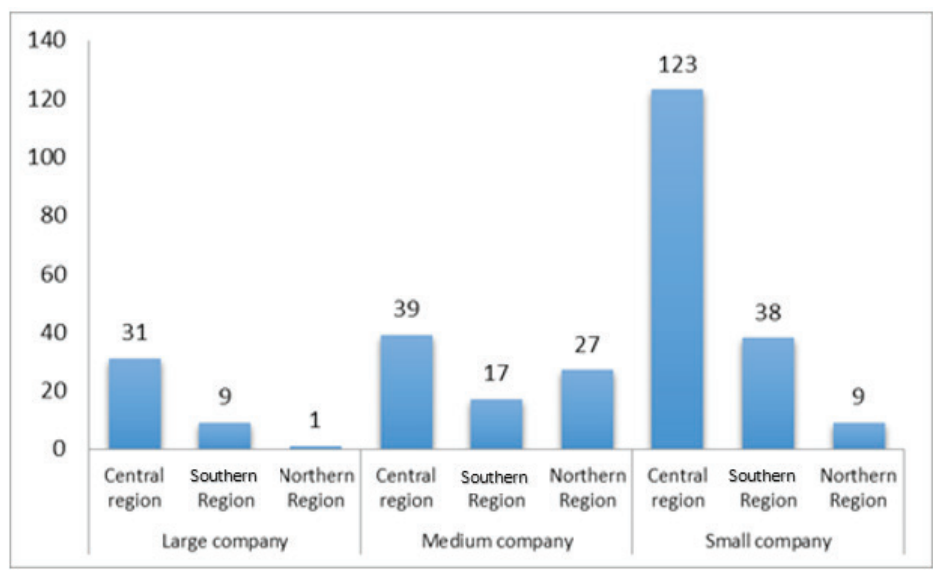


$45 \%$ in Central region and $42 \%$ in Southern region. When analyzing the size of legal entities (Figure 3), it can be noticed that in the case of the sample, small enterprises in the central region are contributing with $40 \%$, medium enterprised with $12 \%$, and large enterprises with $10 \%$. Small legal entities in the Southern region are represented by $12 \%$, medium-sized with $5.6 \%$, and large with $2.9 \%$. Regarding the Northern region of Montenegro, these small enterprises participate with $2.9 \%$, medium $8.9 \%$ and large with only $0.8 \%$. Obviously, this regional representation of enterprises is by definition the reflection of different development of certain regions in Montenegro.

Additionally, the number of respondents from the service activity group and small businesseses outperform respondents from other industries, which can be a limitation that can affect the results of the research.

\subsubsection{The degree of application of IT standards in the field of AIS}

After analysing the answers received by all regions, it is evident that respondents coming from the central part of Montenegro frequently $(17.5 \%)$, or very often $(38.6 \%)$ use the Internet, while it is often used by small enterprises (79\%) (Figure 4). The most commonly cited software solutions that best describe the current accounting system is Integrated Adapted Accounting Software Package (52\%), either Epsilon (8\%) or SAP $(6 \%)$, which are predominantly used in companies of the central part of Montenegro (42.2\%), both by budget and financial institutions as well as by service companies. In the Southern and Northern regions off-theshelf software solutions are more commonly used - in $10.2 \%$ of cases. The widest application of information and communication technologies is observed in companies in the central region, which can be a consequence of the degree of regional development.
Figure 4. The implemantion of I/IT in AIS - size of the company

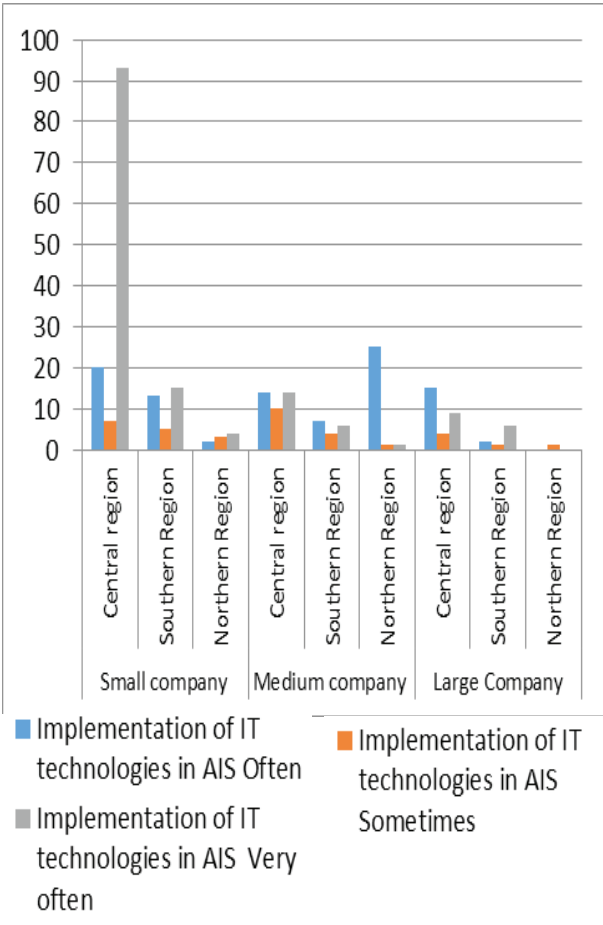

Source: Author's calculation

Having certain software solutions is an initial step and an important platform for the introduction of certain IT newspapers in the AIS domain. Both large business planning systems and systems of local manufacturers are already at the beginning of the digitalization of financial reporting.

In the context of the above, authors were interested in whether there is a statistically significant link between the regions and the use of I and IT in AIS. For this purpose Hi-square test of independence was used (Table 3) where obtained value of 0.000 is less than the Alpha value of 0.05 , and therefore authors concluded that result is statistically significant. That means that the level of application of I and IT within the AIS is statistically different in the respondents of a 
Table 3: Chi-Squere test; Cramer's V indicators

\begin{tabular}{|l|r|r|c|}
\hline \multicolumn{4}{|c|}{ Chi-Square Tests } \\
\hline & Value & df & $\begin{array}{c}\text { Asymptotic } \\
\text { Significance } \\
\text { (2-sided) }\end{array}$ \\
\hline Pearson Chi-Square & $41,607^{\mathrm{a}}$ & 12 & .000 \\
\hline Likelihood Ratio & 42.528 & 12 & .000 \\
\hline N of Valid Cases & 303 & & \\
\hline
\end{tabular}

\begin{tabular}{|l|l|r|c|}
\hline \multicolumn{3}{|c|}{ Cramer's V indicators } \\
\hline \multicolumn{2}{|c|}{} & Value & $\begin{array}{c}\text { Approximate } \\
\text { Significance } \\
\text { (2-sided) }\end{array}$ \\
\hline $\begin{array}{l}\text { Nominal by } \\
\text { Nominal }\end{array}$ & Phi & .371 & .000 \\
\cline { 2 - 4 } & Cramer's V & .214 & .000 \\
\hline \multicolumn{2}{|l|}{ N of Valid Cases } & 303 & \\
\hline
\end{tabular}

Source: Author's calculation

certain region, which, for comparison, was also significant in the first segment of the research. Through Cramer's $V$ indicators, the magnitude of the effect between the observed variables (Table 3) was determined, so that the coefficient V 0.214 is making the conclusion that there is an insignificant correlation between the regional location of the company and the use of I and IT achievements in accounting.

In Law on Accounting (Article 10), it is stated that "Legal person is obliged to submit financial reports and management report in written and electronic ... ". Article 17 reads: "Banks are obliged, in written and electronic form ... and insurance companies, in written and electronic form ..." Starting from the above, authors were interested in the accounting discipline that is in this part between the companies that come from different local government units in Montenegro. Generally speaking, authors found that $87.7 \%$ of respondents submitted financial statements to the competent authority and that from $51 \%$ of respondents financial statements can be obtained at the company's headquarters. However, it is noticed that such a practice is not applied when publishing a report on the website (47\%). If we enter into the analysis of the mentioned issues through the prism of the regional location of the respondents, we note that respondents coming from the southern region do not have the practice of submitting financial statements to the competent authority (48.4\%), but neither of publishing the reports on website (only $7.8 \%$ publish it). (Figure 5) On the other hand, the accounting culture in that part is much more pronounced among the companies from the central part of Montenegro (43\%), which indicates a much higher sensitivity of the entities of a certain activity and the size of the central region which was pointed out in the first part of this research.

Due to the significance of the answers given, authors wanted to determine whether there is a statistically significant difference in the way financial statements are published for companies coming from different local government units or regions. The results of the Hi - Square of Independence test (Table 4) show that the difference is statistically significant, indicating that the methods of financial reporting are significantly different among companies belonging to individual regions, but also that there is a slight degree of association between the way financial statements are published in individual regions (Cramer's $V$ has a value of 0.338)-Table 4.

Authors found that there is a strong connection between the activities of companies coming from the Northern region and the method of publishing financial statements (0.735), while this level of association is lower in the case of the enterprises of the South (0.468) and the Central region (0.483) of Montenegro -Figure 6. 
Figure 5. Forms of financial statements - size of the company

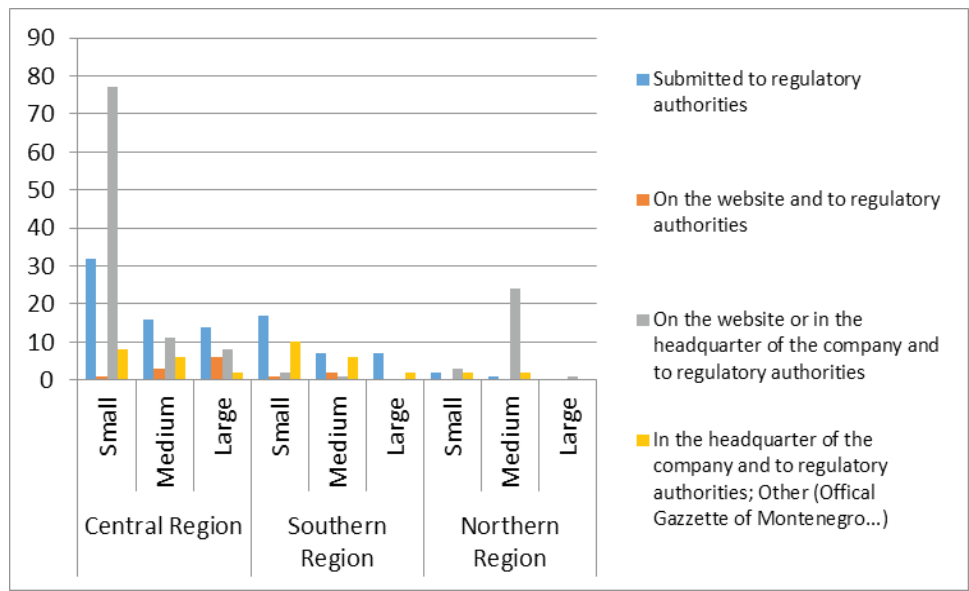

Table 4. Chi-Squere test; Cramer's V indicators

\begin{tabular}{|c|c|c|c|c|c|c|c|}
\hline \multicolumn{4}{|c|}{ Chi-Square Tests } & \multicolumn{4}{|c|}{ Cramer's V indicators } \\
\hline & Value & Df & $\begin{array}{c}\text { Asymptotic } \\
\text { Significance } \\
\text { (2-sided) }\end{array}$ & & & Value & \begin{tabular}{|c} 
Approximate \\
Significance \\
(2-sided) \\
\end{tabular} \\
\hline Pearson Chi-Square & $103,645^{\mathrm{a}}$ & 33 & .000 & Nominal by & Phi & .585 & .000 \\
\hline Likelihood Ratio & 115.325 & 33 & .000 & Nominal & Cramer's V & .338 & .000 \\
\hline $\mathrm{N}$ of Valid Cases & 303 & & & $\mathrm{~N}$ of Valid $\mathrm{C}$ & ases & 303 & \\
\hline
\end{tabular}

Source: Author's calculation

In this part of the research, authors tried to gain insight into the existing practice of financial reporting in different business entitities belonging to the local government units of a particular region. The general conclusion is that the level of perception moves within the limits of legal restrictions and that the exit from certain norms exists in a small degree, in the case of those companies where the influence of foreign capital exists and which have the status of a large legal entity.

Figure 6. The way of submitting financial statements - business sector

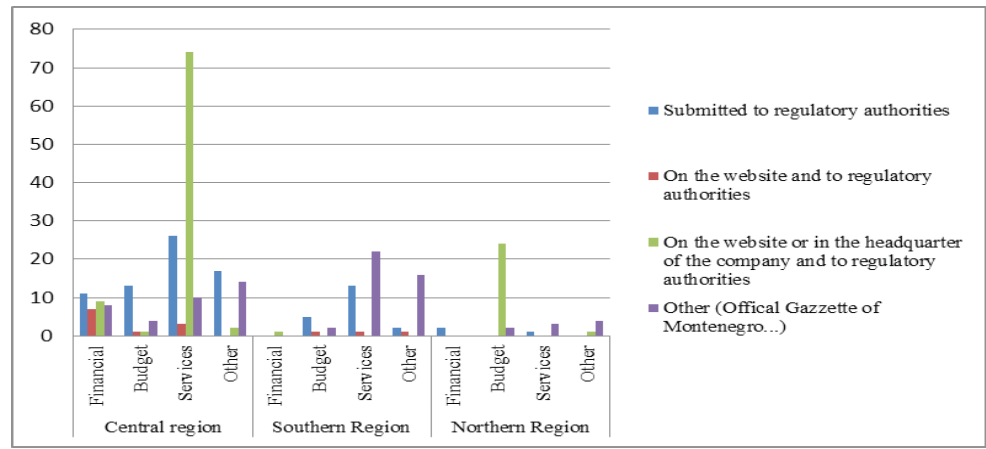




\subsection{Attitudes of regional companies towards introducing technological inno- vations in AIS}

As well as certain revolutionary newspapers of professional accounting regulations created in the $60 \mathrm{~s}$ and $70 \mathrm{~s}$ of the last century, so on the advent of the new millennium appeared the EXtensible Business Reporting Language (XBRL), which represents a new evolutionary shift in the development of financial reporting. Specifically, the XBRL financial statements have been submitted in various formats (pdf, xls, html, doc) which were most often incompatible and hence complicated the process of exchange of information. XBRL is the benchmark for structured business information over the Web and has a focus not only on financial but also on non-financial reporting, and can be used to exchange reportinginformation content in the wider, social and ecological aspects of business operations. At the same time, the XBRL standard understands that timely and reliable information is very important in modern business conditions, so the emphasis is placed on analysis and decision-making (Martić, pp. 123). Due to the importance attached to the new standard for business information exchange, we have been interested in surveying the perception of respondents in Montenegro regarding the mentioned prolematics.

The obtained results indicate a lack of information regarding the application of modern IT solutions $(85 \%)$, as well as the lack of desire for their mplementation $(13.3 \%)$. Observed from the point of view of company's size, medium legal entities of the central region show the highest level of IT awareness $(28.8 \%)$ with the strongest intentions for IT implementation (13.3\%) (Figure 7). Authors estimated that the number of those who possess knowledge of IT standards is most frequent among the respondents employed in large legal entities. This situation can be explained by the fact that large legal entities come to the fore as leaders in implementing XBRL standards globally-Figure 8.

This attitude of the respondents was the result of several factors, but it mainly owes to the fact that there is no legal norm that explicitly states the form of submitting financial statements. Namely, in spite of the numerous changes in the legal accounting

Figure 7. Knowledge of XBRL - size of the company

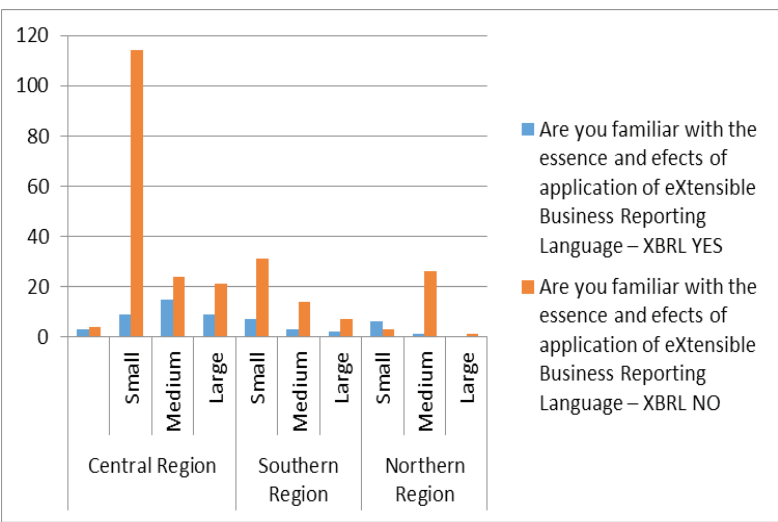

Figure 8. XBRL implementation plan-size of the company

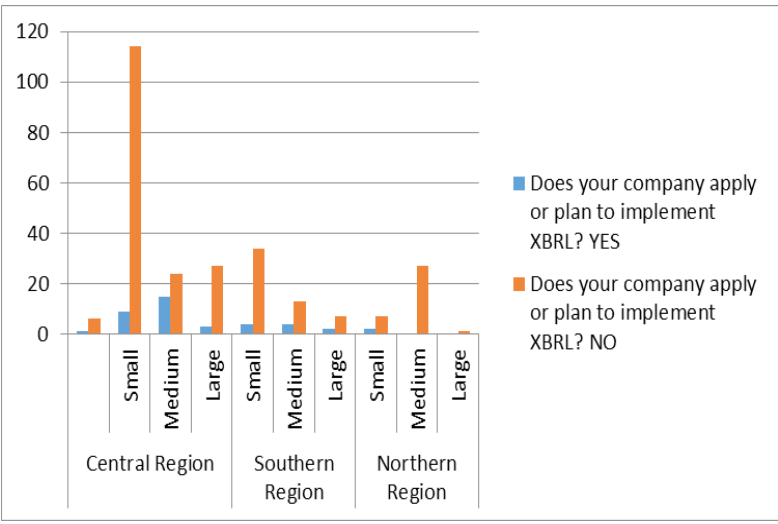


framework, the factor that often violates the discipline of financial reporting is the format of financial statements. There are initiatives concerning the application of new formats, in particular, XBRL, but the legislator has ignored them. New legal solution (issued in July 2016) in this part remained as in previous regulations. Since no standardized communication between regulators and companies has been established, nor between regulatory agencies, companies are obliged to deliver the same reports several times to different agencies. This leads not only to higher spending, but also to less focus on the priority business activities.

Through the second stage of the research authors have come to the conclusion that in general there is little information about the companies, but also about the desire to implement the innovations in the domain of AIS. Difference between the companies varies depending on the activity, size and regional location of the company. Large enterprises in the financial sector of the central region show the highest level of awareness, but also interest in applying XBRL, which is to be expected as the banking sector is predominantly foreign, positioned in the central region of Montenegro.

\section{CONCLUSION}

Considering that there is almost no empirical research that deals with digitalization of financial reporting in local government units in certain regions of Montenegro, authors consider that this paper will serve as a kind of educational base and a secondary source on this subject. At the same time, the results of the survey can provide useful information to the regulatory authorities of the accounting profession that will serve as guidelines for the future creation of national legislation, with the intent of harmonizing the practice of financial reporting with the EU directives.

Several important findings have come from this study that can be used as a basis for future research. Firstly, the degree of development of a particular region can also determine the perception of companies within it in terms of applying modern IT standards in the field of AIS. Namely, it has been established that the Northern region of Montenegro, which is the least developed across all macroeconomic indicators, shows the lowest level of accounting discipline, which has been shown in both segments of the research. This research observation coincides with the research provided by other authors (Ryan et al, 2002, Bolivar et al, 2006, Bolivar et al., 2007).

Secondly, the size and nature of the activities of an enterprise in a particular region may be correlated to a degree with the level of accounting culture that governs them, as confirmed by the research papers of other authors (Ashbaugh et al., 1999; Craven et al, 1999; Ettredge, 2002, Pirchegger et al, 1999, Bonson et al, 2006, Allam et al, 2003, Oyelere et al., 2003, Marston et al, 2008, Ezat et al, 2008; Hussainey et al, 2008,). Neither the application of accounting regulations nor the accompanying acts cannot be excluded. Namely, in the Central region of Montenegro, which represents the economic, social and cultural center of Montenegro, major companies are located, with significant focus on providing financial (banking) services. Through both research approaches authors came to the conclusion that large companies from these regions have the highest level of awareness regarding the purpose of financial reporting. It is noted that the level of perception is within the limits of legal restrictions in the case of those companies that have a foreign capital effect and who have the status of a large legal entity. 
Thirdly, the respondents did not show readiness to apply the "bar code for financial reporting". Authors have found out that the company's information, but also the desire to implement innovation in AIS, varies depending on the activity, size and regional location of the company. Large enterprises in the financial sector of the central region show the highest level of knowledge, but also interest in applying the XBRL, which is to be expected as the banking sector is predominantly owned by foreign capital. Furthermore, research indicates that a large number of different formats for exchange of business information are currently being used (PDF, $\mathrm{xls}, \mathrm{html}$, doc), which is actually the essence of the problem, i.e. the lack of agreement on a uniform format for the exchange of business information prevents their efficient exchange, increases the likelihood of errors and greatly complicates and increases the financial reporting process.

Shortly, this paper provides important insights into the problem of IT for processing and servicing financial information to users, from the perspective of companies in different Montenegrin regions. However, this study has several limitations. The first is a small sample size in the first segment of

\section{REFERENCES}

1. Abdelsalam O. H., Bryant S. M., Street D. L. (2007) An Examination of Comprehensiveness of Corporate Internet Reporting Provided by LondonListed Companies. J. Int. Account. Res. 6(2), 1-33, https://doi.org/10.2308/ jiar.2007.6.2.1

2. Allam, A., Lymer, A. (2003) Developments in Web Financial Reporting: Review and Analysis across Five Developed Countries, International Journal of Digital Accounting Research, 3(6), 165-199, https://doi.org/10.4192/1577-8517-v3_6 the study. In anticipation of the tightening of financial reporting discipline by regulators, authors believe that more companies will increase their awareness of the importance of financial reports, and make their data transparent on their websites, as well as on the stock market website. Therefore, it would be interesting to explore this issue in the future on a larger sample. Secondly, in the focus of the second segment of the research, authors perceived the accounting community as a research group, because of the previously stated reasons. However, authors believe that research should be extended to users of financial information, regulatory government agencies, management, etc., with the intent of acquiring a more complete insight into these issues. Thirdly, through the profile of the respondents in the second segment of the survey, authors noticed that the number of respondents from the service activity group and SME's outperform respondents from other groups, which can be a limitation that can affect the results. Fourthly, the mentioned research focuses only on the local governments of Montenegro. However, authors believe that this research can present an incentive for other researchers to conduct similar research with regional interstate comparison of results.

3. Ashbaugh H., Johnstone K. M., Warfield T. D. (1999) Corporate Reporting on the Internet. Accounting Horizons 13(3), 241-257, https://doi.org/10.2308/ acch.1999.13.3.241

4. Azleen, I., Ghani E. K. (2015) Examinig the Adoption of Extensible Business Reporting Language among Public Listed Company in Malaysia, Procedia Economics and Finance, 38, 38-39, https://doi.org/10.1016/ S2212-5671(15)01078-3

5. Barako DG, Rusmin R, Tower G (2008). Web communication: An Indonesian perspective. Afr. J. Bus. Manage. 2(3), 
53-58, Available online at: http://hdl. handle.net/20.500.11937/36434

6. Bogdan, V., Pop, C. M. (2008) Romanian Companies' Web-Based Disclosure Choices and Capital Markets, Annales Universitatis Apulensis Series Oeconomica, 1(10), Available online at: http://www.oeconomica.uab.ro/upload/ lucrari/1020081/9.pdf

7. Bolivar, M.P.R., Caba Perez, C., Lopez Hernandez, A.M. (2006) Cultural contexts and governmental digital reporting, International Review of Administrative Sciences, 72(2), 269-290, https:// doi.org/10.1177/0020852306064614

8. Bolivar, M.P.R., Caba Pérez, C.,Lopez Hernandez, A.M. (2007) e-Government and public financial reporting: The case of Spanish regional governments, American Review of Public Administration, 37(2), 142-177, https:// doi. org/10.1108/14684520810889682

9. Bonson, E. Cortijo, V., Escobar, T. (2009) A Delphi Investigation to Explain the Voluntary Adoption of XBRL. The International Journal of Digital Accounting Research, 9, 193-205.

10. Bonsón, E., Escobar, T. (2006) Digital reporting in Eastern Europe: An empirical study, International Journal of Accounting Information Systems, 7, 299-318. $\quad$ https://doi.org/10.1016/j. accinf.2006.09.001

11. Brennan N., Hourigan D. (1999) Corporate Reporting on the Internet by Irish Companies, The Irish Accounting Review, 7(1), 37-68, Available online at: http:/www.iafa.ie/uploads/ irish_accounting_review/IRISH $\% 20$ ACCOUNTING\%20REVIEW71.pdf

12. Craven, B., Marston, C. (1999) Financial Reporting on the Web by Leading UK Companies, European Accounting Review, 8, 321-33, https://doi. org/10.1080/096381899336069
13. Cvijetić M., Finansijsko izvještavanje na domaćem web-u, available at: http:// www.mvi.rs/blog? $\mathrm{p}=14$ (31.03.2018)

14. Deller, D., Stubenrath M., Weber C. (1999) A survey on the use of the Internet for investor relations in the USA, the UK and Germany, The European Accounting Review, 8(2), 351-346.

15. Dolinšek, T., Tominc, P., LutarSkerbinjek, A. (2014) Users' perceptions on in-ternet financial reporting. Organizacija: Revija za management, informatiko in kadre, 47(4), 254-266, DOI: 10.2478/ orga-2014-0019

16. Ettredge M, Richardson VJ, Scholz S (2001) The presentation of financial information at corporate Web sites, Int. J. Account. Inform. Syst., 2, 149-168, https://doi.org/10.1016/ S1467-0895(00)00017-8

17. Ezat A, El-Masry A. (2008) The impact of corporate governance on the timeliness of corporate internet reporting by Egyptian listed companies, Manager. Finan., 34(12), 848-867, https://doi. org/10.1108/03074350810915815

18. Felden, C. (2011) Characteristics of XBRL Adoption in Germany, Journal of Management Control, 22(2), 161-186, https://doi.org/10.1007/ s00187-011-0134-7

19. Fisher, R; Oyelere, P., Laswad, F.(2004) Corporate Reporting on the Web: Audit Issues and Content Analysis of Practices, Managerial Auditing Journal, 19(3), 412-439 https://doi. org/10.1108/02686900410524418 
20. Gray, G.L., Miller, D. M. (2009) XBRL: Solving Real-World Problems. International Journal of Disclosure and Governance, 6(3), 207-223, https:// doi.org/10.1057/jdg.2009.8

21. Hodge, F., Pronk, M. (2006) The Impact of Expertise and Investment Familiarity on Investors' Use of Online Financial Report Information, Journal of Accounting, Auditing and Finance, 21(3), 267-292

22. Hoffman, C., Egmond, R. (2012) Digital Financial Reporting Using an XBRLbased Model, Available online at: http://xbrl.squarespace.com/digitalfinancial-reporting/

23. Khalay, B., Farsian, S., Karbalaee, S.M. (2013) Liquidity and Capital Structure: Case of Malaysian Top 100 Public Listed Company, 3rd Asia-Pacific Business Research Conference, Kuala Lumpur, Malaysia, 1-15, Available online at: https://wbiworldconpro.com/uploads/ malaysia-conference-2013/finance/358Bahman.pdf

24. Laswad, F. Fisher, R., Oyelere, P. (2005), Determinants of voluntary web financial reporting by local government authorities, Journal of Accounting and Public Policy, 24, 101-121, https://doi. org/10.1016/j.jaccpubpol.2004.12.006

25. Lymer A, Tallberg, A. (1997) Corporate Reporting and the Internet-a survey and commentary on the use of the WWW in corporate reporting in the UK and Finland, Paper presented at the 20th Annual Congress of the European Accounting Association, Graz (Austria), Available online at: http://web.bham. ac.uk/a.m.lymer/articles/lymereaa.htm.

26. Lymer, A (1999) The Web and the Future of Corporate Reporting in Europe, European Accounting Review, 8 (2), 289-301, https://

\section{doi.org/10.1080/096381899336041}

27. Marston C, Polei A. (2004) Corporate reporting on the Internet by German companies. Int. J. Account. Inform. Syst., 5, 285-311, https://doi. org/10.1108/13563280310458894

28. Marston, C. (2003) Financial reporting on the internet by leading Japanese companies. Corporate Communications, 8(1), 23-34. https://doi.org/10.1108/ 13563280310458894

29. Marston, C. L., Leow, C.Y. (1998) Financial Reporting on the Web by Leading Companies, Paper presented at the 21st Annual Congress of the European Accounting Association, Antwerp, Belgium, Available online at: ftp://ftp.cs.bham.ac.uk/pub/groups/ summa/SUMMA/SUMMA/corp/ papers/marston/marston.html

30. Martić, V. (2017) Primjena XBRL-a u funkciji unapređenja kvaliteta finansijskog izvještavanja u Crnoj Gori, doktorski rad, Univerzitet Mediteran, Podgorica

31. Oyelere P, Laswad F, Fisher R. (2003) Determinants of Internet Financial Reporting by New Zealand Companies. J. Int. Financ. Manage. Account., 14(1), 26-61. https://doi.org/ 10.1111/1467-646X.00089

32. Pervan, I., (2006) Voluntary Financial Reporting On The Internet - Analysis Of The Practice Of Croatian And Slovene Listed Joint Stock Companies, Financial Theory and Practice, 30 (1), 1-27

33. Pervan, I., Bartulović, M., (2017) Determinants of Internet Financial Reporting of Croatian Banks Panel Analysis, EBEEC Conference Proceedings, The Economies of Balkan and Eastern Europe Countries in the Changed World, KnE Social Sciences, 170-181. https://doi.org/10.18502/kss. v1i2.655 
34. Petravick, S., Gillett, J. (1996) Financial reporting on the World Wide Web, Management Accounting, 26-29, Available online at: https://www.coursehero.com/file/p1it935/Petravick-SGillett-J-1996-Financial-reporting-onthe-World-Wide-Web-Management/

35. Pirchegger B, Wagenhofer A. (1999). Financial information on the Internet: a survey of the homepages of Austrian companies. Eur. Account. Rev., 8(2), 383-395, https://doi. org/10.1080/096381899336113

36. Ryan, C., Stanley, T., \& Nelson, M. (2002) Accountability disclosures by Queensland local government councils: 1997-1999, Financial Accountability and Management, 18(3), 261-289, https://doi.org/ 10.1111/1468-0408. 00153

37. Steenkamp, L.P., Nel, G.F. (2012) The adoption of XBRL in South Africa: an empirical study. The Electronic Library, 30(3), 409-425. https://doi. org/10.1108/02640471211241672

38. Wagenhofer, A. (2003) Economic Consequence of Web Financial Reporting, Schmalenbach Business Review, 55(10), 262-279, Available online at: https://papers.ssrn.com/sol3/ papers.cfm?abstract_id $=555042$

39. Zaimović, T., Zaimović, A., Fazlić, A. (2015) Internet financial reporting in Bosnia and Herzegovina, Economic Review - Journal of Economics and Business, XII (2), 21-34.

40. Report of realization of Action Plan of Regional Development Stratefy of Montenegro 2014-2020 (http://www.mek.
gov.me/ResourceManager/FileDownload. aspx? rid $=173411 \&$ rType $=2$, retrieved on: 19.05.2017.)

41. www.gov.me/ResourceManager/ FileDownload. aspx? rId=243695\&rType $=2$, retrieved on: 19.06.2017.

42. http://www.privrednakomora.me/poslovni-ambijent-javne-rasprave-projektiaktuelnosti/informacione-tehnologije-stanje-i-perspektive, retrieved on: 19.06.2017.

43. Law on Accounting of Montenegro http://www.poreskauprava.gov.me/ ResourceManager/FileDownload.aspx? rid $=248374 \& r$ Type $=2 \&$ file $=$ Zakon $\% 20$ o\%20racunovodstvu.doc, retrieved on: 11.05.2017.

44. https://www.monstat.org/cg/

45. http://www.montenegroberza.com/code/ navigate.asp? $I d=1$

46. http://www.mek.gov.me/Resource Manager/FileDownload.aspx? rid= 173411\&rType =2, retrieved on: 19.05.2017.

47. http://durbin.cdtmn.org/durbin/images/ dokumenta/NOVI_PRAVILNIK_O_ IZVJESTAVANJU.p. $d$, retrieved on: 20.05.2017.

48. www.gov.me/ResourceManager/ FileDownload.aspx?rId=243695\&rType=2, retrieved on: 19.06.2017.

49. Law on Banks ("Official Gazette of Montenegro", No. $17 / 08$ of 11.03 $.2008,44 / 10$ of $30.07 .2010,40 / 11$ of 08.08.2011), http://www.cb-cg.org/ slike_i_fajlovi/fajlovi/fajlovi_brzi_linkovi/propisi/zakoni/ zakon_o_bankama4011.pdf, retrieved on: $11 . \overline{0} \overline{2} .2017$. 


\section{DIGITALIZACIJA FINANCIJSKOG IZVJEŠTAVANJA U LOKALNIM VLASTIMA TRIJU REGIJA CRNE GORE - TRENUTNA SITUACIJA I PERSPEKTIVE}

\section{SAŽETAK}

Cilj ovog rada je analizirati razinu digitalizacije procesa financijskog izvještavanja u lokalnim vlastima triju crnogorskih zemljopisnih regija te procijeniti razinu njihove harmonizacije sa suvremenim dostignućima informatizacije računovodstvenih sustava. U svrhu analize glavne hipoteze, koriste se dva istraživačka pristupa (direktna analiza $i$ anketa). U hipotezi se tvrdi da je digitalizacija financijskog izvještavanja u različitim crnogorskim regijama ovisna o računovodstvenoj kulturi poduzeća, ali i o njihovoj veličini, aktivnostima te normativnim aktima. S obzirom da se slično istraživanje nije prethodno provodilo ni u Crnoj Gori, ni u susjednim zemljama, doprinos ove studije se može ocijeniti kao originalan. 